Bangladesh J. Bot. 44(2): 215-221, 2015 (June)

\title{
PHOTOSYNTHETIC PERFORMANCE AND ANTI-OXIDATIVE RESPONSE OF CORNUS CONTROVERSA SEEDLINGS UNDER CADMIUM AND LEAD STRESS
}

\author{
Xiaoxia Huang*, Yonglei Jiang, Xiaomao Cheng, Lilan Deng and Xuncheng Liu ${ }^{1}$ \\ Faculty of Landscape Architecture, Southwest Forestry University, \\ P.O. Box 140, Kunming 650224, China
}

Key words: Photosynthetic performance, Cornus controversa, Lead stress, Cadmium stress, Anti-oxidant enzymes

\begin{abstract}
The photosynthetic efficiency of Cornus controversa leaves was decreased significantly under Cd treatment while it was not affected by $\mathrm{Pb}$ exposure. $\mathrm{Cd}$ decreased while $\mathrm{Pb}$ treatment increased the chlorophyll contents of Cornus controversa leaves. Furthermore, the peroxidase (GPX) activities were decreased after $\mathrm{Cd}$ treatment while elevated by $\mathrm{Pb}$ exposure in Cornus controvera seedlings. In addition, both $\mathrm{Cd}$ and $\mathrm{Pb}$ exposures increased the malondialdehyde (MDA) and proline contents and elevated the superoxide dismutase (SOD) activities of Cornus controvera seedlings. Collectively, these results indicated that Cornus controversa may be more tolerant to $\mathrm{Pb}$ than $\mathrm{Cd}$ toxicity. This finding will contribute to the evaluation of planting Cornus controversa in heavy metal polluted soil conditions.
\end{abstract}

\section{Introduction}

Environmental heavy metal contamination is becoming a worldwide problem that has attracted a great deal of attention. The release of heavy metals into the environment is mainly caused by various anthropogenic activities associated with agricultural practices, mineral exploration, industrial processes and solid waste management (Alumaa et al. 2002). Heavy metal pollution causes serious physiological damage to the plants. Exposure to high levels of heavy metals induces inhibition of nutrient uptake, hindering the activity of photosynthetic apparatus, inhibiting the activation of antioxidant enzymes (Sandalio et al. 2001), and displacing the essential elements in plants. Heavy metals also damage the plant cellular components, such as membranes, nucleic acids, chloroplast pigments, and peroxidizing lipid.

Among the heavy metal pollutants, cadmium $(\mathrm{Cd})$ and lead $(\mathrm{Pb})$ are considered as the most toxic element. The plants subjected to heavy metal contaminations display various morphological, physiological, and biochemical changes, and these changes are usually considered to be the indicators of the degree of heavy metal injury. Photosynthesis is one the most fundamental and intricate physiological processes in higher plants. The mechanism of photosynthesis involves various components, including photosynthetic pigments and photosystems, the electron transport system, and $\mathrm{CO}_{2}$ reduction pathways, any damage caused by a stress may reduce the overall photosynthetic capacity of a green plant (Ashraf and Harris 2013). Heavy metal pollutions such as $\mathrm{Cd}$, copper $(\mathrm{Cu})$, and chromium $(\mathrm{Cr})$ can inhibit the photosynthetic performance of plants by affecting the fluorescence emission kinetic characteristics and photosynthetic pigments of plants (Huseynova et al. 2009, Nagajyoti et al. 2010). Furthermore, the responses of plant natural

*Author for correspondence: <Huangxx8012@gmail.com>. ${ }^{1}$ Key Laboratory of Plant Resources Conservation and Sustainable Utilization, South China Botanical Garden, Chinese Academy of Sciences, Guangzhou 510650, China. 
antioxidant system is a another efficient indicator for heavy metal stresses, which involves a number of enzymes including superoxide dismutase (SOD), peroxidase (GPX), catalase (CAT), and ascorbate peroxidase (APX) (Clijsters et al. 1999). These antioxidant enzymes can protect plant cells from damage caused by superoxide radical reaction products and build a physical barrier against toxic heavy metals (Krantev et al. 2008). Collectively, the photosynthetic performance and anti-oxidative response are two sensitive indicators of plants in response to heavy metal stresses, which can reflect the ability of plants surviving on polluted areas. The photosynthesis performance and anti-oxidant activity of Cornus controversa plants under different concentrations of $\mathrm{Cd}$ and $\mathrm{Pb}$ treatment were studied.

\section{Materials and Methods}

Two-year-old healthy Cornus controversa seedlings of a uniform height $(15-20 \mathrm{~cm})$ were grown in the Southwest Forestry University with a climate condition similar to that of the original site of the Cornus controversa. The seedlings were transplanted to 5 litre plastic pots filled with red soil, perlite and humus soil in the proportion of $3: 3: 2$. The experimental treatments started from 10 September to 10 October, 2012 after the seedlings were transplanted. The seedlings were randomly divided into five groups, each group including10 pots. One was the control and the others were treated with different levels of $\mathrm{Cd}(10 \mathrm{mmol} / \mathrm{l}$ and $20 \mathrm{mmol} / \mathrm{l})$ and $\mathrm{Pb}(5 \mathrm{mmol} / \mathrm{l}$ and $10 \mathrm{mmol} / \mathrm{L}$ ). The $\mathrm{Cd}$ was applied as $\mathrm{CdCl}_{2}$, and the $\mathrm{Pb}$ was applied as $\mathrm{Pb}\left(\mathrm{NO}_{3}\right)_{2}$. For each $\mathrm{Pb}$ treatment, the pots were watered with $10 \mathrm{ml}$ of $\mathrm{Pb}\left(\mathrm{NO}_{3}\right)_{2}$ solution every other day. It is the same as for $\mathrm{Cd}$ treatment. The control was watered $10 \mathrm{ml}$ of water instead of heavy metals solution. The seedlings were collected at days 30, respectively. Various chlorophyll fluorescence, physiological, and biochemical parameters were measured at the end of the experiment. The third or fifth pair of leaves completely unfolded were selected as materials to measure the fluorescence parameters and physiological and biochemical indexes, and at least five seedlings of each repetition were chosen in each treatment.

Chlorophyll fluorescence parameters were performed using the Imaging-PAM M-series (Walz, Effeltrich, Germany) as described by Brugnoli and Björkman (1992). After full dark adaption, leaves were used to determine the $F o$ (the minimal fluorescence after the dark adaptation), the maximum efficiency of $P S I I$ and $F v / F m$. Non-photochemical quenching coefficients $q N$ and photochemical quenching $q P$ coefficients were calculated as described by van Kooten and Snel (1990). The concentrations of chlorophyll $(a, b)$ were calculated using adjusted extinction coefficients (Inskeep and Bloom 1985). The malondialdehyde (MDA) content were measured as described by Hodges et al. (1999). The absorbance of the free proline concentration was measured at $520 \mathrm{~nm}$. Free proline was measured as described by Bates et al. (1973). The proline content was expressed as $\mu \mathrm{g}$ per gram of fresh weight. The total superoxide dismutase (EC 1.15.1.1, SOD) activity was measured spectrophotometrically based on inhibition in the photochemical reduction of nitrobluetetrazolium (NBT) (Beauchamp et al. 1971). The guaiacol peroxidase (EC 1.11.1.7, GPX) activity of leaves was measured as described by Chance and Maehly (1955). Statistical analyses were performed with the statistical software package for social science (SPSS), version 17.0. One-way analyze of variance (ANOVA) were conducted to evaluate the significance of the heavy metal effects. Among all treatments, the means were compared by Duncan's tests at the significance level $(\mathrm{p}<0.05)$.

\section{Results and Discussion}

The $\mathrm{Fv} / \mathrm{Fm}$ and $Y(I I)$ values of Cornus controversa leaves were obviously decreased upon 10 and $20 \mathrm{mmol} / \mathrm{l} \mathrm{Cd}$ exposure, suggesting that Cd treatment may depress the photosynthesis efficiency of the plants (Table 1 ). In contrast, the $F v / F m$ and $Y(I I)$ values were not obvious altered 
after $\mathrm{Pb}$ treatment (Table 1). Fv/Fm indicates the maximum photochemical efficiency of the photosystem II, and $Y(I I)$ illustrates the amount of energy used in photochemistry by photosystem II. Fv/Fm and $Y(I I)$ values are two important indictors reflecting the photosynthesis efficiency of plants. Chlorophyll content is considered as an indictor of damages to photosynthetic system induced by adverse environment (Maxwell and Johnson 2000). Cd treatments decreased both chlorophyll $a$ and $b$ contents of Cornus controversa. In contrast, chlorophyll $a$ and $b$ contents were increased upon $\mathrm{Pb}$ treatment with the increasing concentrations of $\mathrm{Pb}$ (Table 2). Collectively, $\mathrm{Cd}$ might be more toxic to the photosynthetic systems of Cornus controversa than Pb pollution. On the other hand, one of the most important causes of Cd toxicity is that it induces strong iron $(\mathrm{Fe})$ deficiency. Fe is required for the biosynthesis of chlorophyll, and iron-deficient plants often showed decreased levels of chlorophyll. A number of studies have showed that acute Cd stress decreased the chlorophyll content and perturbed the composition of thylakoid complexes (Kapoor et al. 2014). These findings suggested that the decreased level of chlorophyll in Cornus controversa seedlings upon Cd may be caused by Cd induced Fe deficiency. Furthermore, Fe has an intermediate redox potential relative to other electron donors used in photosynthesis, and $\mathrm{Fe}$ is also necessary for the biosynthesis of iron-sulfur proteins in plants. Cd induced Fe deficiency may interfere with the electron transport of the photosystem and thus decrease the photosynthesis efficiency of Cornus controversa seedlings. High level of $\mathrm{Pb}$ toxicity could inhibit chlorophyll

Table 1. Effects of lead and cadmium on chlorophyll fluorescence parameters.

\begin{tabular}{lccccc}
\hline Treatment & Fo & Fv/Fm & Y(II) & qN & qP \\
\hline $\mathrm{CK}^{2+}$ & $0.1077 \pm 0.0141 \mathrm{a}$ & $0.7295 \pm 0.0094 \mathrm{~b}$ & $0.5238 \pm 0.0115 \mathrm{~b}$ & $0.5437 \pm 0.0881 \mathrm{ab}$ & $0.8509 \pm 0.0257 \mathrm{ab}$ \\
$\mathrm{Pb}^{2+} \mathrm{A}$ & $0.1001 \pm 0.0022 \mathrm{a}$ & $0.7158 \pm 0.0065 \mathrm{~b}$ & $0.5533 \pm 0.0314 \mathrm{~b}$ & $0.5363 \pm 0.0345 \mathrm{ab}$ & $0.9127 \pm 0.0419 \mathrm{~b}$ \\
$\mathrm{~Pb}^{2+} \mathrm{B}$ & $0.0942 \pm 0.0128 \mathrm{a}$ & $0.7525 \pm 0.0191 \mathrm{~b}$ & $0.5788 \pm 0.0425 \mathrm{~b}$ & $0.4717 \pm 0.0736 \mathrm{a}$ & $0.8713 \pm 0.0203 \mathrm{ab}$ \\
$\mathrm{Cd}^{2+} \mathrm{A}$ & $0.1441 \pm 0.0120 \mathrm{~b}$ & $0.6672 \pm 0.0252 \mathrm{a}$ & $0.4114 \pm 0.0653 \mathrm{a}$ & $0.6490 \pm 0.0723 \mathrm{~b}$ & $0.8004 \pm 0.1202 \mathrm{ab}$ \\
$\mathrm{Cd}^{2+} \mathrm{B}$ & $0.1477 \pm 0.0096 \mathrm{~b}$ & $0.6582 \pm 0.0300 \mathrm{a}$ & $0.3995 \pm 0.0194 \mathrm{a}$ & $0.6374 \pm 0.0408 \mathrm{~b}$ & $0.7795 \pm 0.0512 \mathrm{a}$ \\
$\mathrm{P}$ & $0.000 * * *$ & $0.001 * *$ & $0.000^{* * *}$ & $0.036 *$ & $0.145 \mathrm{~ns}$ \\
\hline
\end{tabular}

$\mathrm{CK}$, control treatment; $\mathrm{Pb}^{2+} \mathrm{A}$, treatment with $5 \mathrm{mmol} / \mathrm{l} \mathrm{Pb}\left(\mathrm{NO}_{3}\right)_{2}$ solution; $\mathrm{Pb}^{2+} \mathrm{B}$, treatment with $10 \mathrm{mmol} / \mathrm{l}$ $\mathrm{Pb}\left(\mathrm{NO}_{3}\right)_{2}$ solution; $\mathrm{Cd}^{2+} \mathrm{A}$, treatment with $10 \mathrm{mmol} / \mathrm{l} \mathrm{CdCl}$ solution; $\mathrm{Cd}^{2+} \mathrm{B}$, treatment with $10 \mathrm{mmol} / \mathrm{l} \mathrm{CdCl}_{2}$ solution. Values followed by the same letter within a column indicate nonsignificant differences at $\mathrm{p}<0.05$ (DMRT). Each value represents the mean \pm SE of five replicates; the same as follow.

Table 2. Effects of lead and cadmium on chlorophyll content.

\begin{tabular}{lccc}
\hline Treatment & Chl $a(\mathrm{mg} / \mathrm{g} \mathrm{FW})$ & Chl $b(\mathrm{mg} / \mathrm{g} \mathrm{FW})$ & $\mathrm{Chl} b / a$ \\
\hline $\mathrm{CK}$ & $1.026 \pm 0.048 \mathrm{ab}$ & $0.521 \pm 0.079 \mathrm{ab}$ & $0.5063 \pm 0.0201 \mathrm{a}$ \\
$\mathrm{Pb}^{2+} \mathrm{A}$ & $1.291 \pm 0.024 \mathrm{~b}$ & $0.651 \pm 0.035 \mathrm{~b}$ & $0.5041 \pm 0.0177 \mathrm{a}$ \\
$\mathrm{Pb}^{2+} \mathrm{B}$ & $1.706 \pm 0.299 \mathrm{c}$ & $0.842 \pm 0.122 \mathrm{c}$ & $0.4956 \pm 0.0180 \mathrm{a}$ \\
$\mathrm{Cd}^{2+} \mathrm{A}$ & $0.860 \pm 0.031 \mathrm{a}$ & $0.444 \pm 0.028 \mathrm{a}$ & $0.5155 \pm 0.0226 \mathrm{a}$ \\
$\mathrm{Cd}^{2+} \mathrm{B}$ & $0.778 \pm 0.050 \mathrm{a}$ & $0.411 \pm 0.017 \mathrm{a}$ & $0.5286 \pm 0.0120 \mathrm{a}$ \\
$\mathrm{p}$ & $0.000^{* * *}$ & $0.000^{* * *}$ & $0.257 \mathrm{~ns}$ \\
\hline
\end{tabular}

synthesis causing impaired uptake of essential elements and even accelerate the decomposition of chlorophyll (Cenkci et al. 2010), such as, $50 \mathrm{mmol} / \mathrm{l} \mathrm{Pb}$ could decrease chlorophyll content of Pisum sativum (Sengar and Pandey 1996). However, present work showed that 5 and $10 \mathrm{mmol} / \mathrm{l}$ $\mathrm{Pb}\left(\mathrm{NO}_{3}\right)_{2}$ treatments could increase the chlorophyll a/b content of Cornus controversa seedlings. Similar work also showed that low concentration of $\mathrm{Pb}$ exposure elevated the chlorophyll content of Hydrilla verticillata and Jatropha curcas L. (Shu et al. 2012, Singh et al. 2013). These findings suggested that low level of $\mathrm{Pb}$ might have a simulating effect on chlorophyll contents of plants. 
In addition, MDA is a reliable marker that determines oxidative stress under heavy metal pollutions in plants. Therefore, the MDA content was measured in Cornus controversa after exposed to either $\mathrm{Cd}$ or $\mathrm{Pb}$ treatments. A significant increment of MDA content was detected after either $\mathrm{Cd}$ or $\mathrm{Pb}$ treatment (Fig. 1), suggesting that both $\mathrm{Cd}$ and $\mathrm{Pb}$ may promote seriously oxidative damage in the plant cells of Cornus controversa. The result agrees with many previous studies (Posmyk et al. 2005, Foyer and Noctor 2005). To protect from oxidative damage, antioxidant enzymes, such as SOD and GPX are activated to scavenge the radicals. SOD is an essential enzyme, which catalyzes the conversion of superoxide anion to $\mathrm{O}_{2}$ and $\mathrm{H}_{2} \mathrm{O}_{2}$, and its activity is often explained as a way of $\mathrm{O}_{2}$ radical-eliminating ability (Wang et al. 2005). In present study, the SOD activity in Cornus controversa leaves was increased significantly under either Cd or $\mathrm{Pb}$ treatment (Table 3). Enhanced SOD activities in Cornus controversa seedlings under $\mathrm{Cd}$ and $\mathrm{Pb}$ exposure suggested that the plants may start the natural anti-oxidative system to scavenge free $\mathrm{O}_{2}$ radicals. In contrast, a number of studies also revealed the heavy metal toxicities may interfere with the antioxidant defense systems by affecting the enzyme activities (Cheng 2003, Nagajyoti et al. 2010). GPX is reported to catalyze the reduction of $\mathrm{H}_{2} \mathrm{O}_{2}$, organic hydroperoxides, and lipid hydroperoxides to $\mathrm{H}_{2} \mathrm{O}$ and alcohol using GSH and/or other reducing equivalents (Foyer and Noctor 2011). In present work, Cd exposure decreased the GPX activities of Cornus controversa seedlings (Table 3), which probably caused by either the directly inactivation or indirect repression of the production of GPX proteins by Cd. The inhibition of GPX upon Cd may impair the ability of Cornus controversa seedlings in response to oxidative stresses. Additionally, previous studies demonstrated proline is a potent scavenger of ROS in response to oxidative stress (Chen and Dickman 2005). In present work, the proline content was increased 60.5 and 128.2\% under 5 and $10 \mathrm{mmol} / \mathrm{l} \mathrm{Pb}$ treatments respectively, while 77.9 and $221 \%$ under 10 and $20 \mathrm{mmol} / \mathrm{l}$ Cd treatments respectively (Fig. 2). The results were consistent with the report of Schat et al. (1997) on the Silene vulgaris. Hence, the increased accumulation of proline under the $\mathrm{Cd}$ and $\mathrm{Pb}$ treatments, this will help the Cornus controversa seedlings to maintain an osmotic balance within plant cells.

Table 3. Effects of lead and cadmium on antioxidative enzyme activities.

\begin{tabular}{lll}
\hline Treatment & GPX $(\mathrm{mmol}$ guaiacol/min/g/ FW) & SOD (Unit/g FW) \\
\hline $\mathrm{CK}$ & $1.783 \pm 0.284 \mathrm{ab}$ & $245.98 \pm 41.04 \mathrm{a}$ \\
$\mathrm{Pb}^{2+} \mathrm{A}$ & $2.801 \pm 0.883 \mathrm{c}$ & $471.58 \pm 104.70 \mathrm{~b}$ \\
$\mathrm{~Pb}^{2+} \mathrm{B}$ & $1.908 \pm 0.226 \mathrm{~b}$ & $437.02 \pm 96.87 \mathrm{~b}$ \\
$\mathrm{Cd}^{2+} \mathrm{A}$ & $0.912 \pm 0.059 \mathrm{a}$ & $493.41 \pm 65.79 \mathrm{~b}$ \\
$\mathrm{Cd}^{2+} \mathrm{B}$ & $1.191 \pm 0.597 \mathrm{ab}$ & $431.26 \pm 51.06 \mathrm{~b}$ \\
$\mathrm{p}$ & $0.004^{* *}$ & $0.018^{*}$ \\
\hline
\end{tabular}

It is suggested that 2-year-old Cornus controversa seedlings may be more tolerant to $\mathrm{Pb}$ than $\mathrm{Cd}$. These findings will contribute to the evaluation of planting Cornus controversa in heavy metal polluted areas. 


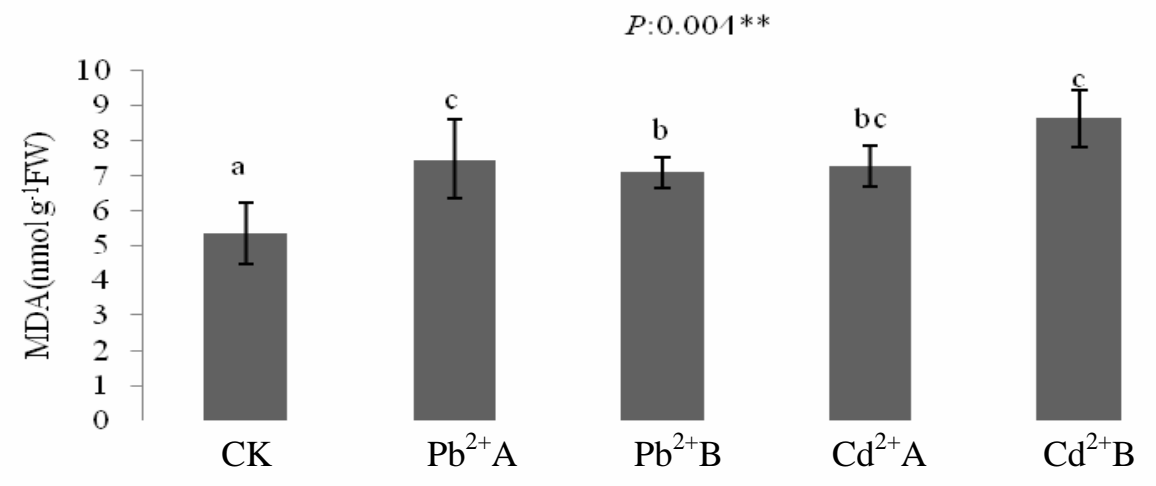

Fig.1 Effects of $\mathrm{Pb}$ and $\mathrm{Cd}$ on MDA content. $\mathrm{CK}$, control treatment; $\mathrm{Pb}^{2+} \mathrm{A}$, treatment with $5 \mathrm{mmol} / \mathrm{l}$ $\mathrm{Pb}\left(\mathrm{NO}_{3}\right)_{2}$ solution; $\mathrm{Pb}^{2+} \mathrm{B}$, treatment with $10 \mathrm{mmol} / \mathrm{l} \mathrm{Pb}\left(\mathrm{NO}_{3}\right)_{2}$ solution; $\mathrm{Cd}^{2+} \mathrm{A}$, treatment with 10 $\mathrm{mmol} / \mathrm{l} \mathrm{CdCl}$ solution; $\mathrm{Cd}^{2+} \mathrm{B}$, treatment with $10 \mathrm{mmol} / \mathrm{l} \mathrm{CdCl}_{2}$ solution. Values followed by the same letter indicate nonsignificant differences at $\mathrm{p}<0.05$ (DMRT). Each value represents the mean $\pm \mathrm{SE}$ of five replicates.

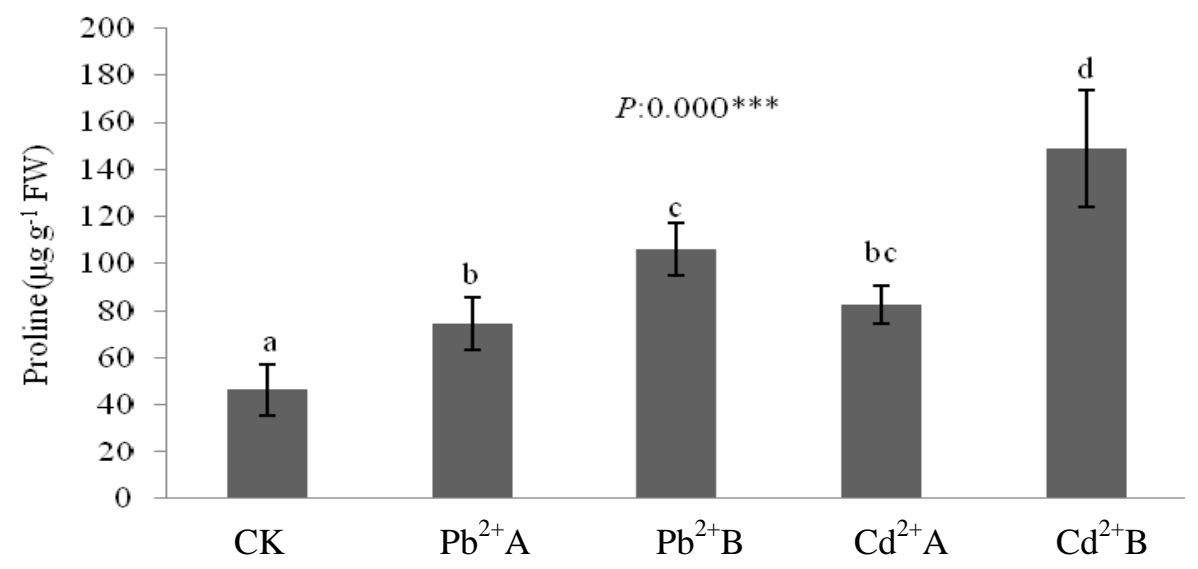

Fig. 2. Effects of $\mathrm{Pb}$ and $\mathrm{Cd}$ on proline content. $\mathrm{CK}$, control treatment; $\mathrm{Pb}^{2+} \mathrm{A}$, treatment with $5 \mathrm{mmol} / \mathrm{l}$ $\mathrm{Pb}\left(\mathrm{NO}_{3}\right)_{2}$ solution; $\mathrm{Pb}^{2+} \mathrm{B}$, treatment with $10 \mathrm{mmol} / \mathrm{l} \mathrm{Pb}\left(\mathrm{NO}_{3}\right)_{2}$ solution; $\mathrm{Cd}^{2+} \mathrm{A}$, treatment with 10 $\mathrm{mmol} / \mathrm{l} \mathrm{CdCl}$ solution; $\mathrm{Cd}^{2+} \mathrm{B}$, treatment with $10 \mathrm{mmol} / \mathrm{l} \mathrm{CdCl}_{2}$ solution. Values followed by the same letter indicate nonsignificant differences at $\mathrm{p}<0.05$ (DMRT). Each value represents the mean $\pm \mathrm{SE}$ of five replicates.

\section{Acknowledgement}

The research was supported by the natural science foundation of Yunnan Province (2010ZC264) and the sharing platform of the Yunnan Provincial and Ministerial Key Discipline, the Key Laboratory of Universities and the laboratory of Colleges.

\section{References}

Alumaa P, Kirso U, Petersell V and Steinnes E 2002. Sorption of toxic heavy metals to soil. Int. J. Hyg. Envir. Heal. 204: 375-376. 
Ashraf M and Harris PJC 2013. Photosynthesis under stressful environments: An overview. Photosynthetica 51: 163-190.

Bates CJ, Waldren RP and Teare ID 1973.Rapid determination of free proline for water-stress studies. Plant Soil 39: 205-207.

Beauchamp C and Fridovich I 1971. Superoxide dismutase: improved assay and an assay applicable to acrylamide gels. Anal. Biochem. 44: 276-287.

Brugnoli E and Björkman O 1992. Chloroplast movements in leaves: Influence on chlorophyll fluorescence and measurements of light-induced absorbance changes related to $\mathrm{DpH}$ and zeaxanthin formation. Photosynth. Res. 32: 23-35.

Cenkci S, Cigerci IH, Yildiz M, Özay C, Bozdag A and Terzi H 2010. Lead contamination reduces chlorophyll biosynthesis and genomic template stability in Brassica rapa L. Environ. Expt. Bot. 67: 467-473.

Chance B and Maehly AC 1955. Assay of catalases and peroxidases. Method Enzymol.2: 764-775.

Chen C and Dickman MB 2005.Proline suppresses apoptosis in the fungal pathogen Colletotrichum trifolii. Proc. Natl. Acad. Sci. USA. 102: 3459-3464.

Cheng S 2003. Effects of heavy metals on plants and resistance mechanisms. A state-of-the-art report with special reference to literature published in Chinese J. Environ. Sci. Pollut. Res. Int. 10: 256-264.

Clijsters H, Cuypers A and Vangronsveld J 1999. Physiological responses to heavy metals in plants; defense against oxidative stress. Z. Naturforsch. C. 54: 730-734.

Foyer CH and Noctor G 2005. Oxidant and antioxidant signaling in plants: a re-evaluation of the concept of oxidative stress in a physiological context. Plant Cell Environ. 28: 1056-1071.

Foyer CH and Noctor G 2011.Ascorbate and glutathione: the heart of the redox hub. Plant Physiol. 155: 2-18.

Hodges DM, Delong JM, Forney CF and Prange RK 1999. Improving the thiobarbituric acid-reactive substances assay for estimating lipid peroxidation in plant tissues containing anthocyanin and other interfering compounds. Planta. 207: 604-611.

Huseynova IM, Suleymanov SY, Rustamova SM and Aliyev JA 2009. Drought-induced changes in photosynthetic membranes of two wheat (Triticumaestivum L.) cultivars. Biochem. 74: 903-909.

Inskeep WP and Bloom PR 1985. Extinction coefficients of chlorophyll $a$ and $b$ in n,n-dimethylformamide and $80 \%$ acetone. Plant Physiol. 77: 483-485.

Kapoor D, Kaur S and Bhardwa JR 2014. Physiological and Biochemical Changes in Brassica juncea Plants under Cd-Induced Stress. Biomed. Res. Int. 2014: 726070.

Krantev A, Yordanova R, Janda T, Szalai G and Popova L 2008. Treatment with salicylic acid decreases the effect of cadmium on photosynthesis in maize plants. J. Plant. Physiol. 165: 920-931.

Maxwell K and Johnson GN 2000. Chlorophyll fluorescence: a practical guide. J. Expt. Bot. 51: 659-668.

Nagajyoti PC, Lee KD and Sreekanth TVM 2010. Heavy metals, occurrence and toxicity for plants : A review. Environ. Chem. Lett. 8: 199-216.

Posmyk MM, Bailly C, Szafranska K, Jana KM and Corbineau F 2005. Antioxidant enzymes and isoflavonoids in chilled soybean (Glycine max (L.)Merr.) seedlings. J. Plant. Physiol. 162: 403-412.

Sandalio LM, Dalurzo HC, Gómez M, Romero-Puertas MC and Del Río LA 2001. Cadmium-induced changes in the growth and oxidative metabolism of pea plants. J. Expt. Bot. 52: 2115-2126.

Schat H, Sharma SS and Vooijs R 1997. Heavy metal-induced accumulation of free proline in metal-tolerant and non-tolerant ecotypes of silene vulgaris. Physiol. Plantarum. 101: 477-482.

Sengar RS and Pandey M 1996. Inhibition of chlorophyll biosynthesis by lead in greening Pisumsativum leaf segments. Biol. Plant. 38: 459-462.

Shu X, Yin LY, Zhang QF and Wang WB 2012. Effect of Pb toxicity on leaf growth, antioxidant enzyme activities, and photosynthesis in cuttings and seedlings of Jatrophacurcas L. Environ. Sci. Pollut. Res. Int. 19: 893-902. 
Singh A, Kumar CS and Agarwal A 2013. Effect of lead and cadmium on aquatic plant Hydrilla verticillata. J. Environ. Boil. 34: 1027-1031.

van Kooten O and Snel JFH 1990. The use of chlorophyll fluorescence nomenclature in plant stress physiology. Photosynth. Res. 25: 147-150.

Wang FZ, Wang QB, Kwon SY, Kwak SS and Su WA 2005. Enhanced drought tolerance of transgenic rice plants expressing a pea manganese superoxide dismutase. J. Plant. Physiol. 162: 465-472.

(Manuscript received on 28 December, 2014; revised on 12 April, 2015) 